\title{
Pengaruh Sistem Pengendalian Intern Pemerintah Terhadap Kinerja Organisasi Perangkat Daerah Di Provinsi Sumatera Selatan
}

\author{
Welly \\ Fakultas Ekonomi dan Bisnis Universitas Muhammadiyah Palembang, welly.Iht@gmail.com
}

\begin{abstract}
ABSTRAK
Sistem pengendalian intern pemerintah yang dikenal dengan SPIP merupakan pedoman dalam menjalankan aktivitas yang terdiri dari lima komponen yaitu lingkungan pengendalian, penilaian resiko, aktifitas pengendalian dan informasi dan komunikasi serta pemantauan. Tujuan dari penelitian ini adalah untuk mengetahui besarnya pengaruh sistem pengendalian intern pemerintah terhadap kinerja Organisasi Perangkat Daerah di Provinsi Sumatera Selatan.Penelitian ini menggunakan jenis penelitian asosiatif, Data yang digunakan data primer dan sekunder.Teknik pengumpulan data yaitu menggunakan kuesioner.Metode analisis dan teknik analisis data yang digunakan dalam penelitian ini adalah asosiatif.Hasil analisis menunjukkan bahwa sistem pengendalian intern pemerintah berpengaruh terhadap kinerja organisasi perangkat daerah di Provinsi Sumatera Selatan.
\end{abstract}

Kata Kunci: Sistem Pengendalian Intern Pemerintah, Kinerja

\begin{abstract}
The government internal control system known as SPIP is a guideline in carrying out activities consisting of five components, namely the control environment, risk assessment, control activities and information and communication and monitoring. The purpose of this study was to determine the magnitude of the influence of the government's internal control system on the performance of Regional Apparatus Organizations in South Sumatra Province. This research uses associative research. The data used are primary and secondary data. The technique of collecting data is using a questionnaire. The method of analysis and data analysis techniques used in this study are associative. The results of the analysis show that the government's internal control system has an effect on the performance of regional apparatus organizations in South Sumatra Province.
\end{abstract}

Keywords: Government Internal Control System, Performance

\section{A. PENDAHULUAN}

Pemerintah daerah dituntut agar memiliki kinerja berorientasi pada kepentingan masyarakat dan mendorong pemerintah untuk senantiasa tanggap dengan lingkungannya, dengan berupaya memberikan pelayanan terbaik secara transparan dan berkualitas serta adanya pembagian tugas yang baik pada pemerintah.Kinerja Organisasi Perangkat Daerah (OPD) adalah gambaran mengenai tingkat pencapaian pelaksanaan suatu kegiatan/ program/kebijakan dalam mewujudkan sasaran, tujuan, misi dan visi organisasi yang tertuang dalam strategic planning suatu organisasi (Mahsun, 2016: 81). Kinerja pemerintah adalah salah satu bentuk penilaian asas manfaat dan efisiensi dalam penggunaan anggaran keuangan dalam organisasi sektor publik, setelah adanya operasional anggaran langkah selanjutnya adalah pengukuran kinerja untuk menilai prestasi dan akuntabilitas organisasi dan manajemen dalam menghasilkan pelayanan publik yang baik.

Menurut Romney dan John Steinbart (2017: 198) kinerja instansi pemerintah berhasil atau tidaknya akan dipengaruhi oleh sistem pengendalian intern pemerintah untuk mencapai tujuan seperti perlindungan aset, menyimpan catatan secara 
terperinci, memberikan informasi yang akurat dan dapat diandalkan, menyiapkan laporan keuangan sesuai dengan aturan yang ditetapkan, meningkatkan efisiensi operasional, mendorong kepatuhan terhadap kebijakan manajerial yang ditentukan dan mematuhi hukum dan peraturan yang berlaku.Kinerja berhasil atau tidaknya akan dipengaruhi oleh tingkat komitmen, baik komitmen dari organisasi atau perusahaan terhadap karyawan maupun antara karyawan terhadap organisasi serta perusahaan sangat diperlukan melalui komitmen yang telah ditetapkan dan akan tercipta iklim kerja yang professional. Sehingga semakin tinggi komitmen seseorang terhadap tugasnya maka akan semakin tinggi kinerja yang akan dihasilkan, yang menuju pada tingkat penilaian yang semakin tinggi.

Berdasarkan PP No. 60 Tahun 2008 tentang Sistem Pengendalian Intern adalah proses yang integral pada tindakan dan kegiatan yang dilakukan secara terus menerus oleh pimpinan dan seluruh pegawai untuk memberikan keyakinan memadai atas tercapainya tujuan organisasi melalui kegiatan yang efektif dan efisien, keandalan pelaporan keuangan, pengamanan aset manfaat yang diharapkan seperti peningkatan kinerja yang merupakan bagian dari Akuntabilitas Kinerja Instansi Pemerintah.Sistem pengendalian intern yang dikeluarkan Committee of Sponsoring Organizations of the Treadway Commission (COSO) terdiri dari lima komponen, yaitu lingkungan pengendalian, penilaian resiko, aktifitas pengendalian dan informasi dan komunikasi serta pemantauan. Pelaksanaan sistem pengendalian intern harusnya bertumpu pada pengutan sistem pengendalian intern yang sudah terbangun dan dilaksanakan oleh seluruh aktor dalam organisasi mulai dari adanya kebijakan, pembentukan organisasi, penyiapan anggaran, sarana dan prasarana, penetapan personil yang dilaksanakan, penetapan prosedur dan reviuw pada seluruh tahapan pembangunan.

Badan Pemeriksaan Keuangan (BPK) menyoroti lemahnya sistem pengendalian internal kementrian/lembaga dalam pengelolaan keuangan.Hasil pemeriksaan atas Laporan Keuangan Kementerian Lembaga (LKKL) mengungkapkan setidaknya 29 temuan signifikan yang disebabkan lemahnya sistem pengendalian internal dan ketidakpatuhan terhadap ketentuan perundang-undangan. BPK menemukan 11 masalah terkait kelemahan sistem pengendalian dalam pemeriksaan laporan keuangan (Agung Firman Sampurna, 2017). Sistem pengendalian intern pemerintah (SPIP) pada tahun 2017 memperoleh hasil sangat tidak memuaskan.Rendahnya nilai kematangan maturitas ini disebabkan tidak terdokumentasinya setiap kegiatan. Tidak adanya dokumentasi menjadi masalah tersendiri ketika melakukan kegiatan pemeriksaan ke Satuan Perangkat Kerja Daerah (SKPD). Buruknya penilaian yang yang diperoleh ini disebabkan kurangnya Sumber Daya Manusia (SDM) dan keterbatasan waktu sehingga menjadi hambatan dalam melakukan pengawasan.

Ketidaknyamanan wakil rakyat atas kinerja Organisasi Perangkat Daerah (OPD) dilingkungan Pemerintah Kota Palembang yang dianggap tidak maksimal saat ini Laporan komisi-komisi terkait rancangan peraturan daerah (Raperda) tentang anggaran pendapatan dan belanja daerah perubahan (APBDP) tahun 2017 saat ini masih ada program OPD pemerintah kota palembang yang belum berjalan. Masih banyak OPD yang tidak memahami berbagai kegiatan yang telah dilaksanakan di dinas masing-masing dan masih banyak OPD tidak paham kegiatan yang telah dianggarkan dan dilaksanakan (Fauzi achmad, 2017). Saat ini masih ada program pemerintah Kota Palembang yang belum berjalan. Seperti Dinas Komunikasi dan Informatika Kota Palembang sampai sekarang program smart city belum berjalan 
padahal rencana itu sudah ada sejak lama dan sudah masuk dalam anggaran. Selain itu masih banyak OPD yang tidak memahami berbagai kegiatan yang telah dilaksanakan didinas masing-masing (Fauzi achmad, 2017).

Pemerintah Kota Palembang belum menyelesaikan laporan keuangan tahun 2017. Sesuai peraturan, laporan keuangan pemerintah daerah harus diserahkan selambat-lambatnya tiga bulan setelah tahun anggaran berakhir lambatnya penyerahan laporan keuangan ini disebabkan karena masih ada empat (OPD) yang belum menyerahkan laporannya. Empat OPD yang belum menyelesaikan laporan keuangan tersebut adalah Dinas Pekerjaan Umum dan Penataan Ruang (PUPR), Perumahan Rakyat dan Kawasan Pemukiman (Pera KP), Dinas Pendidikan (Disdik) dan Dinas Kesehatan (Dinkes) (Harobin, 2018).

Penelitian Sebelumnya yang dilakukan oleh Nur Azlina dan Ira Amelia (2014) disimpulkan bahwa tata kelola dan control internal memiliki pengaruh positif dan signifikansi pada kinerja pemerintah dikabupaten Pelalawan. Sistem pengendalian intern pemerintah membawa kinerja yang signifikan pada pemerintah daerah. Penelitian Nur dkk (2018) dapat disimpulkan bahwa variable sistem pengendalian intern pemerintah, sistem informasi manajemen daerah dan kualitas sumber daya manusia berpengaruh positif signifikan terhadap kinerja manajerial aparatur pemerintah daerah.Adapun tujuan dari penelitian ini adalah untuk mengetahui pengaruh sistem pengendalian intern pemerintah (SPIP) terhadap kinerja organisasi perangkat daerah (OPD) di Provinsi Sumatera Selatan.

\section{B. KAJIAN TEORI}

\section{Sistem Pengendalian Intern Pemerintah (SPIP)}

Berdasarkan PP No. 60 Tahun 2008 Sistem Pengendalian intern adalah proses yang integral pada tindakan dan kegiatan yang dilakukan secara terus menerus oleh pimpinan dan seluruh pegawai untuk memberikan keyakinan memadai atas tercapainya tujuan organisasi melalui kegiatan yang efektif dan efisien, keandalan pelaporan keuangan, pengamanan aset negara, dan ketaatan terhadap peraturan perundang-undangan. Sistem Pengendalian Intern dapat juga diartikan sebagai suatu sistem yang digunakan untuk mengamankan harta kekayaan perusahaan, menjamin ditaatinya kebijakan manajemen dan menciptakan efisiensi dan efektifitas perusahaan.Sistem Pengendalian Internal meliputi struktur organisasi, metode dan ukuran-ukuran yang dikoordinasikan untuk menjaga aset organisasi, mengecek ketelitian dan keandalan data akuntansi, mendorong efisiensi dan mendorong dipatuhinya kebijakan manajemen (Mulyadi, 2016: 129).Sistem Pengendalian intern adalah proses yang dirancang untuk menyediakan jaminan yang wajar mengenai pencapaian tujuan dalam keandalan pelaporan keuangan, efektifitas dan efisiensi operasi, dan kepatuhan terhadap hukum dan peraturan yang berlaku (Bodnar dan William, 2013: 12). Menurut Romney dan Paul John Steinbart (2017: 198) Sistem pengendalian internal adalah proses yang dilaksanakan untuk memberikan jaminan yang masuk akal.

Berdasarkan beberapa pendapat (Bodnar dan William, 2013: 113-123, PP nomor 60 Tahun 2008, COSO, 2013: 4-7, Marshall dan Steinbart, 2018: 204-221) maka dapat disimpulkan komponen sistem pengendalian intern adalah sebagai berikut:

a) Lingkungan pengendalian, merupakan dampak kolektif faktor untuk membangun, mendukung, dan meningkatkan efektivitas kebijakan dan prosedur tertentu. 
b) Penilaian resiko, merupakan proses mengidentifikasi perubahan kondisi internal dan eksternal dan tindakan terkait yang mengkin diperlukan.

c) Kegiatan pengendalian, merupakan kebijakan dan prosedur yang dibuat untuk membantu memastikan bahwa arahan manajemen dilaksanakan dengan baik.

d) Informasi dan komunikasi, Informasi mengacu pada sistem akuntansi organisasi, yang terdiri dari metode dan catatan yang diciptakan untuk mengidentifikasi, merangkai, menganalisis, mengelompokkan, mencatat, dan melaporkan transaksi organisasi untuk memelihara akuntabilitas aktiva dan utang yang terkait. Dan komunikasi terkait dengan memberikan pemahaman yang jelas mengenai semua kebijakan dan prosedur yang terkait dengan pengendalian.

e) Pemantauan, Pemantauan melibatkan proses yang berkelanjutan untuk menaksir kualitas pengendalian internal dari waktu kewaktu serta untukmengambil tindakan koreksi yang diperlukan.

\section{Kinerja Instansi Pemerintah}

Kinerja Instansi Pemerintah Daerah merupakan gambaran mengenai tingkat pencapaian pelaksanaan suatu kegiatan/program/kebijaksanaan dalam mewujudkan sasaran, tujuan, misi dan visi organisasi yang tertuang dalam perumusan skema strategis suatu organisasi. Menurut (Mahsun, 2016: 81) definisi kinerja instansi pemerintah daerah adalah gambaran mengenai tingkat pencapaian pelaksanaan suatu kegiatan/program/ kebijakan dalam mewujudkan sasaran, tujuan, misi dan visi organisasi yang tertuang dalam strategic planning suatu organisasi.

Berdasarkan pendapat (Mahsun, 2016: 81) maka dapat disimpulkan pengertian kinerja instansi pemerintah adalah gambaran mengenai tingkat pencapaian pelaksanaan suatu kegiatan/program/kebijaksanaan pengguna anggran keuangan dalam organisasi publik, setelah adanya operasional anggran langkah selanjutnya adalah pengukuran kinerja untuk menilai prestasi dan akuntabilitas organisasi dengan tujuan untuk mencapai sasaran, tujuan, misi dan visi organisasi.

Sistem pengukuran kinerja sektor publik adalah suatu sistem yang bertujuan untuk membantu manajer publik menilai pencapaian suatu strategi melalui alat ukur financial dan nonfinansial. Tujuan dari sistem pengukuran kinerja adalahuntuk mengkomunikasikan strategi secara lebih baik.Untuk mengukur kinerja financial dan nonfinancial secera berimbang sehingga dapat ditelusuri perkembangan pencapaian strategi. Untuk mengakodomasi pemahaman kepentingan menejer level menengah dan bawah serta memotivasi untuk mencapai goal congruence. Sebagai aat untuk mencapai kepuasan berdasarkan pendekatan individual dan kemampuan kolektif yang rasional (Mardiasmo, 2002: 122).

Berdasarkan beberapa indikator yang telah dijelaskan para ahli (Mahsun, 2013:

71) maka indikator yang digunakan pada penelitian ini adalah:

a) Indiaktor masukan (input), Indikator masukan (inputs): Jumlah dana yang dibutuhkan. Jumlah pegawai yang dibutuhkan. Jumlah infrastruktur yang ada. Jumlah waktu yang dibutuhkan.

b) Indikator proses (process): Ketaatan pada peraturan perundangan. Rata-rata yang diperlukan untuk memproduksi atau menghasilkan layanan jasa.

c) Indikator keluaran (output): Jumlah produk atau jasa yang dihasilkan. Ketepatan dalam memproduksi barang atau jasa.

d) Indikator hasil (outcome): Tingkat kualitas produk atau jasa yang dihasilkan. Produktivitas para karyawan atau pegawai. 
e) Indikator manfaat (benefit): Tingkat kepuasan masyarakat.Tingkat partisipasi masyarakat

f) Indikator impact: Peningkatan kesejahteraan masyarakat. Peningkatan pendapatan masyarakat

\section{Kerangka Pemikiran dan Hipotesis}

Menurut Romney dan John Steinbart (2017: 198) kinerja instansi pemerintah berhasil atau tidaknya akan dipengaruhi oleh sistem pengendalian intern pemerintah untuk mencapai tujuan seperti perlindungan aset, menyimpan catatan secara terperinci, memberikan informasi yang akurat dan dapat diandalkan, menyiapkan laporan keuangan sesuai dengan aturan yang ditetapkan, meningkatkan efisiensi operasional, mendorong kepatuhan terhadap kebijakan manajerial yang ditentukan dan mematuhi hokum dan peraturan yang berlaku.

Kinerja instansi pemerintah berhasil atau tidaknya akan dipengaruhi oleh sistem pengendalian intern merupakan bagian yang sangat penting dalam mekanisme pengendalian keseluruhan yang digunakan untuk memotivasi, mengukur dan memberi sanksi atas tindakan-tindakan manajer dan karyawan dari suatu organisasi. Sistem pengendalian yang efektif merupakan prasyarat bagi kinerja yang lebih baik. Pengunaan sistem pengendalian akan menyebabkan peningkatan kinerja organisasi dengan mendorong pengambilan keputusan oleh para manajer secara lebih baik, maka kerangka pemikiran dapat dilihat pada gambar sebagai berikut ini:

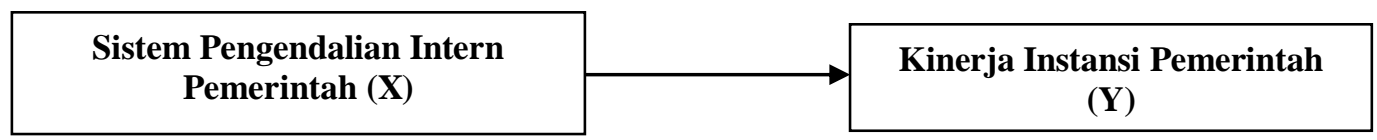

\section{Gambar: Kerangka Pemikiran}

Berdasarkan uraian kerangka pemikiran diatas maka dapat disusun seperti: Terdapat Pengaruh Sistem Pengendalian Intern Pemerintah Terhadap Kinerja Instansi Pemerintah.

\section{METODE PENELITIAN}

Jenis penelitian yang digunakan asosiatif untuk mengetahui pengaruhSistem Pengendalian Intern Pemerintah Terhadap Kinerja Organisasi Perangkat Daerah. Lokasi Penelitian yang dilakukan pada Organisasi Perangkat Daerah (OPD) pada Provinsi Sumatera Selatan. Variabel yang digunakan adalah Sistem pengendalian intern pemerintah (SPIP) dengan indikator lingkungan pengendalian, penilaian resiko, kegiatan pengendalian, informasi dan komunikasi, pemantauan. Populasi penelitian adalah OPD Provinsi Sumatera Selatan yang berjumlah 27 OPD. Responden Penelitian terdiri dari: Kepala Organisasi Perangkat Daerah (OPD), Kepala Akuntansi, Staf Keuangan danBagian Kepegawaian. Data yang digunakan data primer dan sekunder (Anwar Sanusi; 2016). Teknik yang digunakan dalam pengumpulan data menggunakan kuesioner.

\section{HASIL PENELITIAN}

Survei penelitian ini adalah 27 OPD yang dijadikan sebagai objek penelitian, namun dari 27 Organisasi Perangkat Daerah terdapat 19 Organisasi Perangkat Daerah yang bisa di survei.Pengumpulan data dengan cara penyebaran kuesioner, berikut profil responden; 
TabelProfil Responden

\begin{tabular}{|c|c|c|c|}
\hline \multicolumn{2}{|c|}{ Keterangan } & Frekuensi & Persentase \\
\hline \multirow{5}{*}{ Jenis Kelamin } & Pria & 37 & $49 \%$ \\
\hline & Wanita & 35 & $46 \%$ \\
\hline & Tidak & & \\
\hline & Teridentifikasi & 4 & $5 \%$ \\
\hline & Jumlah & 76 & $100 \%$ \\
\hline \multirow{7}{*}{ Umur } & $<20$ & 0 & $0,00 \%$ \\
\hline & $<20-30$ & 15 & $20 \%$ \\
\hline & $<31-40$ & 25 & $33 \%$ \\
\hline & $>41-50$ & 16 & $21 \%$ \\
\hline & $\begin{array}{l}>50 \\
\text { Tidak }\end{array}$ & 11 & $14 \%$ \\
\hline & Teridentifikasi & 9 & $12 \%$ \\
\hline & Jumlah & 76 & $100 \%$ \\
\hline \multirow{7}{*}{$\begin{array}{l}\text { Tingkat } \\
\text { Pendidikan }\end{array}$} & SMA/SMK & 2 & $3 \%$ \\
\hline & $D-1$ & 7 & \\
\hline & D-II & 0 & $00,0 \%$ \\
\hline & D-III & 4 & $5 \%$ \\
\hline & S1 & 44 & $58 \%$ \\
\hline & $\begin{array}{l}\text { S2 } \\
\text { Tidak }\end{array}$ & 15 & $20 \%$ \\
\hline & Teridentifikasi & 4 & $5 \%$ \\
\hline \multirow{7}{*}{$\begin{array}{l}\text { Latar Belakang } \\
\text { Pendidikan }\end{array}$} & Jumlah & 76 & $100 \%$ \\
\hline & Akuntansi & 9 & $12 \%$ \\
\hline & Manajemen & 12 & $16 \%$ \\
\hline & Perbankan & 2 & $3 \%$ \\
\hline & $\begin{array}{l}\text { Lain-lain } \\
\text { Tidak }\end{array}$ & 36 & $44 \%$ \\
\hline & Teridentifikasi & 17 & $22 \%$ \\
\hline & Jumlah & 76 & $100 \%$ \\
\hline \multirow{5}{*}{ Masa Kerja } & $<3$ bulan & 4 & $5 \%$ \\
\hline & $<1$ tahun & 11 & $14 \%$ \\
\hline & $\begin{array}{l}>1 \text { tahun } \\
\text { Tidak }\end{array}$ & 55 & $73 \%$ \\
\hline & Teridentifikasi & 6 & 8 \\
\hline & Jumlah & 76 & $100 \%$ \\
\hline
\end{tabular}

Sumber: Data diolah, 2020 


\section{Uji Asumsi Klasik}

\section{Uji Normalitas}

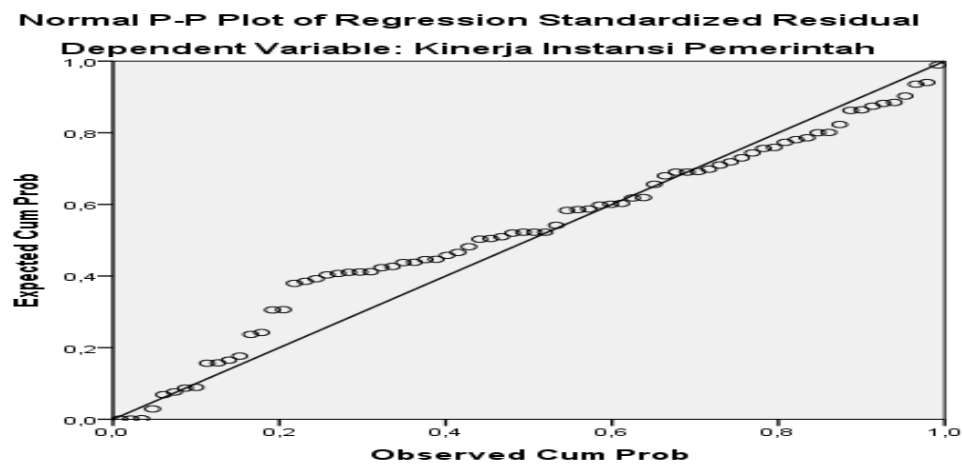

Sumber: Data diolah, 2020

\section{Gambar Normal P-P Plot}

Berdasarkan gambar terlihat bahwa titik-titik menyebar disekitar garis diagonal dan penyebarannya mengikuti arah garis diagonal. Dapat disimpulkan bahwa model regresi ini layak dipakai karena memenuhi distribusi normalitas.

\section{Uji Heteroskedastisitas}

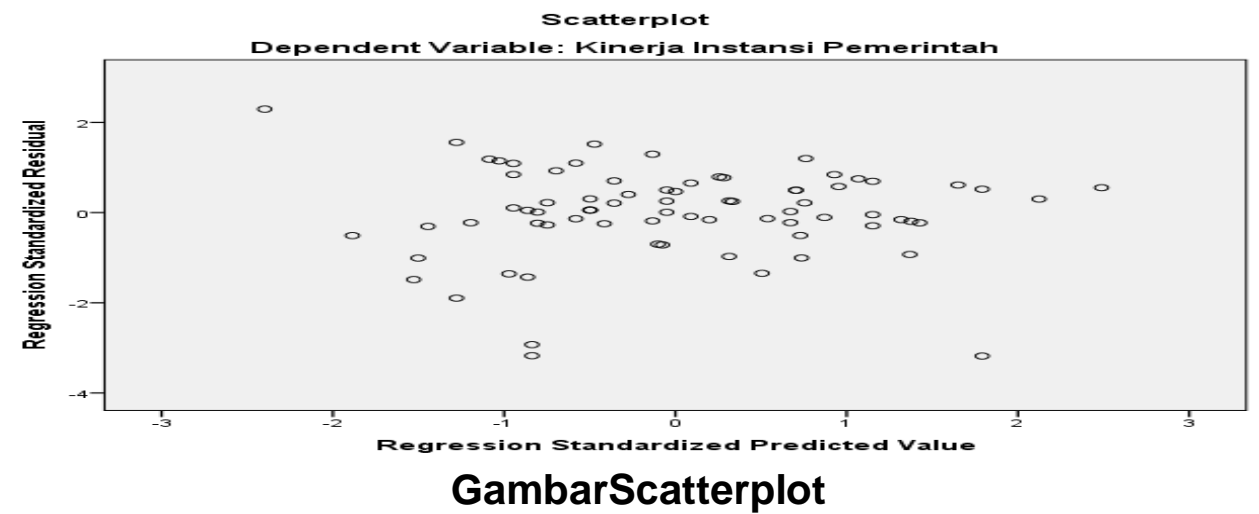

Sumber: Data Diolah, 2020

Berdasarkan gambar maka dapat disimpulkan bahwa tidak ada pola yang jelas seperti titik-titik menyebar di atas dan di bawah angka 0 pada sumbu $\mathrm{Y}$ maka tidak terjadi heteroskedastisitas.

\section{Analisis Regresi}

TabelHasil Uji Analisis Regresi

Coefficients $^{\mathrm{a}}$

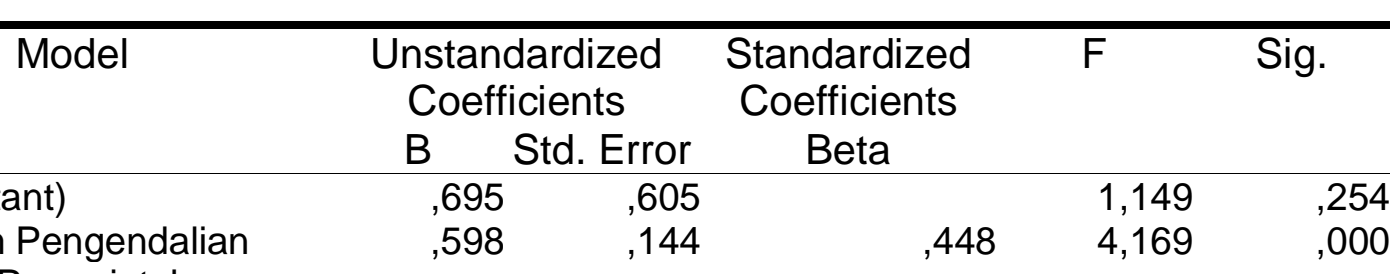

1 Sistem Pengendalian 
Berdasarkan Tabel diatas hasil regresi berganda menunjukkan bahwa variabel sistem pengendalian intern pemerintah $(\mathrm{X})$ terhadap kinerja instansi pemerintah $(\mathrm{Y})$ dapat dilihat persamaan regresinya sebagai berikut:

$$
\begin{aligned}
& Y=a+b_{1} X_{1}+b_{2} X_{2}+e \\
& Y=0,695+0,598 X 1+e
\end{aligned}
$$

\section{Uji Koefisien Determninasi $\left(\mathbf{R}^{2}\right)$}

Koefisien Determinasi $R^{2}$ (adjusted $R$ square) sebesar 0,290 artinya 29,0\% variabel sistem pengendalian intern pemerintah dapat dijelaskan oleh variabel kinerja instansi pemerintah (dependen) sedangkan sisanya sebesar $71,0 \%$ dipengaruhi oleh faktor lain yang tidak termasuk dalam penelitian ini.

\section{Uji Hipotesis}

Hasil uji hipotesis menunjukkan bahwa diketahui nilai thitung untuk variabel sistem pengendalian intern pemerintah $(X)$ sebesar 4,169 sedangkan nilai $t_{\text {tabel }}$ dengan taraf nyata 0,05 (5\%) adalah sebesar 1,993. Jadi dapat disimpulkan bahwa $\mathrm{H}_{0}$ ditolak dan Ha diterima Karena nilai thitung $(4,169)>t_{\text {tabel }}(1,993)$. Hasil uji hipotesis secara parsial untuk variabel sistem pengendalian intern pemerintah (X) menunjukkan bahwa variabel tersebut secara signifikan mempengaruhi kinerja instansi pemerintah ( $\mathrm{Y}$ ). Hal ini digambarkan dengan ditolaknya $\mathrm{H}_{0}$ dan diterimanya Ha serta nilai signifikan $X$ sebesar $0,00<0,05$ berarti sistem pengendalian intern pemerintah $(X)$ secara signifikan mempengaruhi kinerja instansi pemerintah $(Y)$.

\section{Pembahasan}

Hasil analisis dan uji hipotesis yang telah dilakukan menunjukkan bahwa sistem pengendalian intern pemerintah berpengaruh signifikan terhadap kinerja instansi pemerintah. Berdasarkan hasil penelitian yang telah dilakukan pada Organisasi Perangkat Daerah Provinsi Sumatera Selatan dapat disimpulkan bahwa secara keseluruhan penerapan sistem pengendalian intern pemerintah di Organisasi Perangkat Daerah di Provinsi Sumatera Selatan termasuk dalam kategori baik. Hal ini terlihat dari tanggapan responden mengenai penerapan sistem pengendalian intern pemerintah yang terdiri dari beberapa indikator. Hasil penelitian ini sesuai dengan teori yang menyatakan bahwa dalam kinerja instansi pemerintah, pengawasan intern membantu mendeteksi dan mencegah berbagai pengaruh lingkungan terhadap sistem.

Dari hasil tanggapan responden tentang penerapan sistem pengendalian intern pemerintah bahwa indikator lingkungan pengendalian, penilaian risiko, aktivitas pengendalian, informasi dan komunikasi, dan pemantauan mempunyai pengaruh terhadap kinerja instansi pemerintah.Dalam suatu OPD Pimpinan dan seluruh karyawan perlu memegang komitmen dimana seseorang membuat perjanjian atau keterikatan baik kepada diri sendiri maupun orang lain yang tercermin dalam tindakan/perilaku sehingga dapat menghasilkan dampak positif bagi suatu OPD dan proses kinerja instansi pemerintah dapat berjalan dengan baik. Seorang pemimpin harus berintegritas yang artinya memiliki pribadi yang jujur dan memiliki konsitensi dalam proses bekerja sehingga dapat menghasilkan kinerja instansi pemerintah yang berkualitas. Nilai-nilai etika merupakan perilaku bagaimana seseorang melakukan sesuatu dengan cara tertentu, baik buruknya perilaku seseorang akan mempengaruhi masukan dan keluaran dalam meningkatkan kinerja instansi 
pemerintah, pimpinan perlu menunjukkan perilaku yang baik agar dapat memberikan manfaat bagi karyawan dalam bekerja sama antar tim.

Pimpinan perlu menunjukkan independensi dari manajemen dalam pengembangan pelaksanaan sistem pengendalian intern pemerintah untuk memastikan bahwa kinerja instansi pemerintah di OPD dalam keadaan baik.Independensi dapat mempengaruhi kinerja instansi pemerintah karena apabila pimpinan menunjukkan independensi dalam suatu OPD, maka bisa menghasilkan keamanan dalam kinerja instansi pemerintah karena posisi OPD tidak terikat dengan pihak manapun.PimpinanOPD di Provinsi Sumatera Selatan juga perlu menjalankan fungsi pengawasan dalam pengembangan pelaksanaan sistem pengendalian intern pemerintah, fungsi pengawasan dalam pengembangan pelaksanaan intern dibutuhkan dalam memberikan kemudahan pemakai serta menghindari salah saji informasi yang dilakukan oleh pegawai. Pimpinan OPD di Provinsi Sumatera Selatan juga perlu meyakinkan pegawai bertanggung jawab atas tugas dan tanggung jawab sistem pengendalian intern pemerintah karena berpengaruh terhadap masukan (input) dalam menghasilkan kinerja instansi pemerintah yang berkualitas.

OPD di Provinsi Sumatera Selatan perlu menetapkan struktur, jalur-jalur pelaporan, wewenang-wewenang dan tanggungjawab dalam mengejar tujuan untuk memadukan efesiensi teknis dengan kepekaan terhadap kebutuhan perusahaan dan pegawai.Struktur organisasi dapat memberikan dampak yang besar untuk perusahaan yang mana struktur organisasi dapat diimplementasikan sesuai dengan sistem kerja organisasi untuk tujuan organisasi yang efektif dan efisien. Dan sturuktur organisasi menentukan bagaimana cara pembagian tugas dan kepada siapa tugas harus dilaporkan. Dengan menetapkan struktur organisasi dapat mempengaruhi hasil kinerja instansi pemerintah yang lebih berkualitas.

Memberikan wewenang dan tanggungjawab telah dikomunikasikan dengan jelas dan dipahami oleh pegawai.Kejelasan wewenang dan tanggungjawab memiliki pengaruh terhadap keamanan data dalam OPD karena telah ditetapkan wewenang serta tanggungjawab tentang siapa saja yang berwewenang untuk mengubah sistem data yang ada pada OPD. Hal ini diharapkan akan menimbulkan suasana yang kondusif sehingga tujuan organisasi dapat tercapai secara efektif serta memberikan kemudahan bagi OPD dalam pengambilan keputusan sehingga dapat menghasilkan kinerja instansi pemerintah yang berkualitas.

Melaksanakan penilaian risiko secara komprehensif di dalam sebuah OPD merupakan proses mengidentifikasi perubahan kondisi secara internal dan eksternal serta tindakan yang terkait dan mungkin diperlukanmelakukan penilaian resiko, penilaian resiko juga merupakan kontribusi penting yang dapat dilakukan oleh internal audit. Pimpinan harus selalu aktif dalam mendapatkan data dan informasi lengkap yang digunakan untuk penilaian resiko yang efektif akan dapat mengidentifikasi risiko-risiko terhadap keamanan kinerja instansi pemerintah yang tidak terdeteksi dan memperkuat kemampuan organisasi dalam mencegah penyalahgunaan sistem yang terjadi di OPD. Sistem pengendalian intern harus memberikan penilaian atas risiko yang dihadapi OPD baik dari luar maupun dari dalam.

Pimpinan organisasi perangkat daerah di Provinsi Sumatera Selatan harus selalu aktif dalam mendapatkan data dan informasi secara lengkap, terbaru, dan tepat waktu agar OPD mampu menghasilkan laporan keuangan yang bebas dari salah saji material.Besarnya suatu kesalahan atau salah saji dalam laporan keuangan yang membuat pengguna laporan keuangan terpengaruh oleh informasi 
yang dihilangkan atau membuat keputusan yang berbeda jika informasi yang benar diketahui.Pimpinan memiliki kewajiban untuk mendeteksi adanya kekliruan dan ketidakberesan yang menyebabkan laporan keuangan berisi salah saji yang material. Penilaian resiko berpengaruh terhadap kinerja instansi pemerintah untuk menjamin keandalan kinerja instansi pemerintah dalam proses yang akurat dan bebas dari kesalahan.

Pimpinan OPD di Provinsi Sumatera Selatan juga perlu mempertimbangkan potensi penipuan.Potensi penipuan berpeluang besar terjadi ketika ada kesempatan.Oleh karena itu OPD perlu mempertimbangkan potensi terjadinya penipuan karena memiliki pengaruh terhadap kinerja instansi pemerintah dalam pencapaian tujuan organisasi karena dapat memperkecil kemungkinan terjadinya penipuan yang dilakukan oleh karyawan. Potensi penipuan juga memiliki pengaruh terhadap kinerja instansi pemerintah dalam proses data secara akurat, lengkap dan bebas dari kesalahan.

Aktivitas atau kegiatan pengendalian diperlukan untuk memilih dan mengembangkan aktivitas pengendalian umum atas teknologi untuk mendukung tercapainya tujuan, sebab kegiatan pengendalian merupakan kebijakan dan prosedur yang dibuat untuk membantu memastikan bahwa arahan manajemen dilaksanakan dengan baik Mengembangkan teknologi dilakukan agar dapat memberikan kemudahan pemakai sehingga dapat meningkatkan kinerja instansi pemerintah yang berkualitas serta terhindari dari salah saji informasi. Mengembangkan teknologi pada OPD di Provinsi Sumatera Selatan juga dapat menghasilkan keandalan kinerja instansi pemerintah yang dapat membantu OPD dalam memproses data yang bermanfaat serta berdampak baik dan bebas dari kesalahan. Mengembangkan teknologi dalam aktivitas pengendalian juga dapat memberikan kemudahan untuk diakses oleh pegawai OPD serta memiliki kemudahan untuk dipahami oleh pegawai dengan adanya aktivitas pengendalian dalam mengembangkan teknologi dalam meningkatkan kinerja instansi pemerintah yang berkualitas.

Informasi dan komunikasi (information and communication) merupakan tonggak penting dalam meningkatkan kinerja instansi pemerintah yang berkualitas dan relevan untuk mendukung fungsi pengendalian internal. Informasi dan komunikasisangat diperlukan bagi entitas untuk melakukan kontrol internal tanggung jawab dan untuk mendukung pencapaian tujuannya. OPD perlu berkomunikasi dengan pihak internal maupun eksternal mengenai hal-hal yang mempengaruhi fungsi pengendalian internal agar tindak kecurangan atau salah saji informasi secara sengaja tidak terjadi lagi. Analisis ini dilakukan untuk menentukan dampak dari sistem informasi yang berkualitas terhadap pengambilan keputusan yang telah dilakukan. Melaksanakan informasi dan komunikasi merupakan kontribusi penting dalam menghasilkan informasi akuntansi yang berkualitas serta mendukung pencapaian fungsi sistem pengendalian intern pemerintah yang baik.

Pemantauan juga sangat berpengaruh terhadap kinerja instansi pemerintah karena dalam proses pemantauan dapat memilih, mengevaluasi, mengembangkan, serta mengkomunikasikan kekurangan pengendalian intern sehingga mempermudah Organisasi Perangkat Daerah dalam pengambilan keputusan. Mengevaluasi kekurangan pengendalian intern juga berpengaruh terhadap kualitas hasil kinerja instansi dalam menghasilkan keandalan. Dengan keandalan sistem informasi dapat membantu pegawai dalam memproses data secara akurat, lengkap, dan bebas dari kesalahan serta menghindari salah saji informasi akuntansi secara sengaja atau tidak jujur. 
Dengan dilakukan pemantauan secara rutin terhadap sistem pengendalian intern pemerintah pada OPD guna menemukan kelemahan, menghindari penyalahgunaan dalam laporan keuangan dan memperbaiki efektivitas sistem pengendalian intern pemerintah yang berkelanjutan dan memastikan bahwa sistem pengendalian intern pemerintah masih sesuai dan berfungsi seperti yang diharapkan. Pemantauan dapat dilakukan dengan inspeksi secara langsung oleh pimpinan OPD pada saat kegiatan pelayanan atau melaksanakan pekerjaan. Inspeksi langsung ini dilakukan untuk memastikan bahwa kinerja instansi pemerintah dalam kategori baik .

Hasil penelitian ini didukung oleh teori yang dikemukakan Romney dan John Steinbart (2017: 198) kinerja instansi pemerintah berhasil atau tidaknya akan dipengaruhi oleh sistem pengendalian intern pemerintah untuk mencapai tujuan seperti perlindungan aset, menyimpan catatan secara terperinci, memberikan informasi yang akurat dan dapat diandalkan, menyiapkan laporan keuangan sesuai dengan aturan yang ditetapkan, meningkatkan efisiensi operasional, mendorong kepatuhan terhadap kebijakan manajerial yang ditentukan dan mematuhi hokum dan peraturan yang berlaku.

Kinerja instansi pemerintah berhasil atau tidaknya akan dipengaruhi oleh sistem pengendalian intern pemerintah merupakan bagian yang sangat penting dalam mekanisme pengendalian keseluruhan yang digunakan untuk memotivasi, mengukur dan memberi sanksi atas tindakan-tindakan manajer dan karyawan dari suatu organisasi. Sistem pengendalian yang efektif merupakan prasyarat bagi kinerja yang lebih baik. Pengunaan sistem pengendalian akan menyebabkan peningkatan kinerja organisasi dengan mendorong pengambilan keputusan oleh para manajer secara lebih baik (Fogelberg dan Griffith, 2000). Hasil penelitian ini juga didukung oleh penelitian Sebelumnya yang dilakukan oleh Nur Azlina dan Ira Amelia (2014) dengan judul "Pengaruh Good Governace dan Pengendalian Intern Terhadap Kinerja Pemerintah Kabupaten Palalawan" Hasil penelitian ini menunjukkan bahwa semua variable vailid, reable, dan penuh asumsi. Hasil analisis hipotesis menunjukkan tata kelola dan pengendalian internal memiliki positif dan signifikansi berpengaruh pada kinerja pemerintah dikabupaten Pelalawan.

Penelitian sebelumnya dilakukan oleh Noval Hadi Praja (2015) dengan judul "Pengaruh Komitmen Organisasi, Sistem Pengendalian Intern Pemerintah Dan Peran Pengelola Keuangan Daerah Terhadap Kinerja Manajerial Satuan Kerja Perangkat Daerah Kota Pekan Baru" Hasil penelitian ini menunjukkan bahwa pengaruh komitmen organisasi, pengaruh sistem control internal pemerintah dan peran manajer keuangan dari kinerja manajerial memiliki berpengaruh signifikan terhadap efektifitas manajerial kinerja itu besarnya efek (R2) Komitmen organisasi, sistem pengendalian intern pemerintah dan peran manajer keuangan area kinerja manajerial adalah $28 \%$. Sedangkan sisanya $72 \%$ dipengaruhi oleh variable independen lain yang tidak diamanati dalam penelitian ini.Penelitian sebelumnya yang dilakukan oleh Nur Jannah Abdi Aziz (2018) dengan judul "Pengaruh Sistem Pengendalian Intern Pemerintah, Sistem Informasi Manajemen Daerah Dan Kualitas Sumber Daya Manusia Terhadap Kinerja Manajerial Aparatur Pemerintah Daerah" Hasil penelitian ini menunjukkan sistem pengendalian intern pemerintah, sistem informasi manajemen daerah dan kualitas sumber daya manusia berpengaruh positif signifikan terhadap kinerja manajerial aparatur pemerintah daerah. 


\section{E. KESIMPULAN DAN SARAN}

1) Kesimpulan

Berdasarkan hasil penelitian bahwa sistem pengendalian intern pemerintah (SPIP) berpengaruh terhadap kinerja instansi pemerintah, dalam penelitian ini terbukti secara empiris bahwa sistem pengendalian intern pemerintah (SPIP) mempengaruhi kinerja instansi pemerintah pada Organisasi Perangkat Daerah di Sumatera Selatan.

\section{2) Saran}

Berdasarkan kesimpulan dari hasil penelitian maka terdapat beberapa saran yang dapat menjadi bahan pertimbangan untuk penelitian sejenis berikutnya.

1. Organisasi Perangkat Daerah Sumatera Selatan lebih meningkatkan lagi sistem pengendalian intern pemerintah di dalam suatu organisasi.

2. Penelitian selanjutnya diharapkan dapat menambahkan variabel dependen lainnya, menambahkan variabel moderating atau intervening yang bertujuan untuk mengetahui variabel-variabel lain yang dapat mempengaruhi variabel independen.

\section{DAFTAR PUSTAKA}

Agung Firman Sampurna, 2018. BPK Soroti Lemahnya Sistem Pengendalian Internal Kementrian/Lembaga.Antaranews,Jakarta.

https://m.antaranews.com/berita/631918/bpk-soroti-lemahnya-sistempengendalian-internal-kementrianlembaga

Anwar Sanusi, 2016. Metodologi Penelitian Bisnis. Cetakan Keenam. Selemba Empat. Jakarta:

Fauzi Achmad, 2017. Kinerja OPD Pemkot Palembang di Anggap Tidak Maksimal. Palembangbaru.com. Palembang. http://palembangbaru.com/kinerja-opdpemkot-palembang-dianggap-tidak-maksimal/

George H. Bodnar dan William S. Hoppwood, 2013. Accounting Informasi Syistem.Eleventh Edition.Florida Atlantic.

Harobin Mustofa, 2018. BPK Deadline Laporan Keuangan Pemkot Palembang. Beritapagi.com. Palembang. http://beriapagi.co.id/2018/01/22/bpk-deadlinelaporan-keuangan-pemkot-palembang.html

Mahsun Mohamad, 2016. Pengukuran Kinerja Sektor Publik. Edisi Pertama. BPFE.Yogyakarta.

Marshall B. Romney dan Paul John Steinbart, 2017. Accounting Informasi Systems.Fourteenth Edition. Pearson. Arizona State.

Mardiasmo. 2002. Akuntansi sector Publik. Penerbit Andi. Yogyakarta.

Mulyadi, 2016. Sistem Akuntansi. Selemba Empat. Jakarta. 
Noval Hadi Praja, 2015. Pengaruh Komitmen Organisasi Sistem Pengendalian Intern Pemerintah Dan Peran Pengelola Keuangan Daerah Terhadap Kinerja Manajerial Satuan Kerja Perangkat Daerah Kota Pekan Baru.Jurnal Fekom Vol. 2, No. 2 Oktober 2015.

Nur Azlina dan Ira Amelia, 2014. Pengaruh Good Governance Dan Pengendalian Intern Terhadap Kinerja Pemerintah Kabupaten Pelalawan. Jurnal Akuntansi Universitas Jember. Vol. 12, No. 2 Desember 2014

Nur Jannah Abdi Aziz, Umi Pratiwi dan Eko Suyono, 2018. Pengaruh Sistem Pengendalian Intern Sistem Informasi Manajemen Daerah Dan Kualitas Sumber Daya Manusia Terhadap Kinerja Manajerial Aparatur Pemerintah Daerah.Jurnal Ekonomi Bisnis dan Akuntansi. Vol. 20, No. 04 Tahun 2018

Peraturan Pemerintah Republik Indonesia Nomor 60 Tahun 2008 tentang Sistem Pengendalian Intern Pemerintah

Syaiful Bahri, 2018. Metode Penelitian Bisnis Lengkap Dengan Teknik Pengelolaan Data SPSS. Penerbit Andi (Anggota IKAPI). Cetakan CV Andi offset. 